Ambient Science, 2018: Vol. 05(Sp2); 37-42

DOI:10.21276/ambi.2018.05.sp2.ra06

\title{
Plant Regeneration through Somatic Embryogenesis of Clerodendrum serratum 1. and the Respective Study on its Antioxidant Activity and Phenolic Content
}

\section{Seema Upadhyay*, Sonal Khandelwal, Vijaya Koche}

School of Studies in Life Sciences, Pt. Ravishankar Shukla University, Raipur, Chhattisgarh, India,

\section{Study Area: Raipur Chhattisgarh, India Coordinates: $21.25^{\circ} \mathrm{N} ; 81.63^{\circ} \mathrm{E}$}

Key words: In vitro regeneration, Medicinal plant

Abbreviation: 2,4-D =2,4-dichlorophenoxyacetic acid; NAA =ánaphthalene acetic acid; BAP =6- benzylaminopurine; LD =Light and Dark; Kn =Kinetin; NEC =non embryogenic callus; $\mathrm{PEC}=$ pre embryogenic callus; SEGH somatic embryo in globular and heart shaped stage; SECG =somatic embryo in cotyledonary and germinating stage; $\mathrm{WP}$ =wild plant; $\mathrm{FCR}=$ FolinCiocalteu reagent; GAE =gallic acid equivalent; DMRT =Duncan's multiple range test.

\section{Introduction:}

Plant produces a number of pharmacologically important chemicals, which are having great importance in the production of phytomedicine. In the present scenario, due to the adverse effect of allopathic medicine, nowadays people are attracting towards the medicine derived from plants/ herbal origin. Clerodendrum serratum L. is one of the important medicinal plant from family lamiaceae. Earliar C. serratum. was kept in the family verbnaceae but after the phylogenetic study on chloroplast DNA some of the genus of this family was shifted to the lamiaceae family and $C$. serratum. was renamed as Rotheca serrata L. (Steane et al., 1997). The leaf and root of this plant have much medicinal value. According to the traditional knowledge roots of this plant are the good source of drugs for diseases like "asthma, body-ache, bronchitis, cholera, dropsy, eye diseases, fever, inflammations, malaria, ophthalmia, rheumatism, snakebite, tuberculosis, ulcers and wounds" (Keshava Murthy, 1994). Leaves of the C. serratum. are used to increase appetite and an expectorant. Its leaves, young shoots, and flowers are used as vegetables. It is one of the

\section{Abstract}

Clerodendrum serratum L. is an important medicinal plant used in Ayurveda, Siddha and Urani treatments to cure many ailments like chronic bronchial asthama, syphilis, typhoid, cancer, jaundice and hypertension. Unfortunately, due to unrestricted harvesting and less effort for its cultivation, it has been identified as an endangered species. The present study was aimed to develop an indirect somatic embryogenesis technique for in vitro cultivation of $C$. serratum and to extract the pharmacologically important secondary metabolites from it. Growth regulators deprivation caused positive stimulation for somatic embryogenesis. Different stages of embryo development such as globular, heart and torpedo stage were observed in embryogenic calli. Antioxidant activity and total phenolic content were also compared between the non-embryogenic callus, different stages of embryogenic callus and wild plant. Antioxidant activity and total phenolic content were high in embryogenic callus as compared to the wild plant. This is the first report of in vitro regeneration of $C$. serratum through somatic embryogenesis that can be used to produce a large number of plants and plant products.

few medicinal plants that shows antagonistic effect on histamine (Chopra et al., 1956). Its phytochemical and biochemical studies reveal that it is a good source of antioxidants (Bhujbal et al., 2009) and contain a number of secondary metabolites like phenolic and flavonoids (Kajaria et al., 2011). Medicinal importance of $C$. serratum. caused its unrestricted exploitation, and now it has become an endangered species according to Chhattisgarh medicinal plant board. The present research work was undertaken to develop an efficient in vitro somatic embryogenesis protocol for $C$. serratum. and to compare the phytochemical contents of the cultures developed at different stages from a wild plant.

Somatic embryogenesis refers to a process which results in obtaining bipolar somatic embryos or non-sexual cells through a series of developmental stages similar to those occurring during in vivo embryogenesis. This is a method of in vitro vegetative propagation first developed for Daucus carota (Steward et al., 1958; Reinert, 1958). Somatic embryogenesis is one of the most promising approaches for plant propagation due to the production of 
large numbers of plantlets (Martin, 2004), the possibility of producing synthetic seeds (Manjkhola et al., 2005; Kumar \& Chandra, 2014) the ability to store and rapidly mobilize germplasm for cryopreservation (Ming-Hua \& Sen-Rong, 2010), the opportunity for genetic manipulation and production of bioactive compounds within a short period of time (Jeong et al., 2005). It is necessary to develop methods for mass clonal propagation and conservation to satisfy the pharmaceutical demand of high valued medicinal plants like $C$. serratum.

\section{Methodology:}

For the study, we used all the chemicals of analytical grade available from Hi- Media, S.D. Fine chemicals, Merck, Sigma chemicals and Qualigens.

Plant samples were collected from the nursery of Energy Park Raipur (C.G.), identified by the "Botanical Survey of India Allahabad (Accession No.- 101218) and planted in the garden of our University for further use. For callus induction, young growing leaves were collected and used as explants. Explants were surface sterilized by the method of Verma et al. (2016).

For the preparation of Culture media and callus induction, all media used in the present study were MS basal medium supplemented with different concentration $(0.5,1.0 \& 2.0 \mathrm{mg} / \mathrm{L})$ of $2,4-\mathrm{D}, \quad \mathrm{NAA}$ and BAP alone or in combination. The $\mathrm{pH}$ of the media was adjusted to 5.8, gelled with $0.8 \%$ Difco-bacto agar before autoclaving at $121^{\circ} \mathrm{C}$ and $103.4 \mathrm{kPa}$ for $15^{-20} \mathrm{~min}$. Sterilized leaves were cut into small pieces and ten explants were inoculated in each media combination. Each experiment was repeated three times. All the cultures were incubated under $16 / 8 \mathrm{hrs}$. LD condition with cool white fluorescent lights of intensity $100 \mu \mathrm{E} / \mathrm{m}^{2}$ at $25 \pm 1^{\circ} \mathrm{C}$ temperature. Further multiplication of callus was done in the same media combination.

For somatic embryogenesis callus was subcultured in basal MS media supplemented with a combination of auxin $(2,4-\mathrm{D} \& \mathrm{NAA})$ and cytokinin (BAP) in different concentrations $(0.25,0.5,1.0,2.0 \mathrm{mg} / \mathrm{L})$. A number of somatic embryos developed were recorded after four weeks of subculturing. All the globular and heart-shaped callus were subcultred into the fresh media of same hormonal combination. Number of torpedo and cotyledonary stage embryo was recorded after four weeks of subculturing.

Torpedo and cotyledonary stage embryos were subcultured in fresh basal MS medium supplemented with different concentration (0.5, 1.0 \& 2.0 mg/L) of BAP and Kn for regeneration into plantlets. Cotyledonary stage somatic embryos were transferred to growth regulator-free MS basal medium to evaluate the effect of the above growth regulators on germination and conversion into plantlets. A number of Somatic embryos germinated were recorded after four weeks of subculturing. Acclimatization and transfer of plantlets to soil were done by following the prescribed method of Hariprasath et al. (2015).
Cultures in different stages of development i.e., NEC, PEC, SEGH, SECG as well as aerial parts of wild plant were taken, shade dried and ground into fine powder. Five gram of each sample were extracted in methanol by soxhlet apparatus. The filtrate was evaporated to dryness in an electric oven. The obtained crude extract was packed in airtight plastic containers and stored in the refrigerator at $20^{\circ} \mathrm{C}$ for furtheranalysis.

Total antioxidant activity was measured by phosphomolybdanum method (Prieto et al., 1999). This method is based on the reducing capacity of antioxidants which reduce phosphomolybdic acid reagent into green colored phosphomolybdanum complex. The antioxidant activity is expressed as the number of gram equivalent of ascorbic acid (mg AS/g).

All five extracts were subjected for determination of total phenolic content by the method of Slinkard \& Singleton (1977). The total phenolic content was expressed as Gallic acid equivalent (mg GAE/g).

SPSS (version 16) software was used to analyze the data. A minimum of 20 explants was cultured for each treatment. All the experiments were repeated thrice and the standard deviation and standard error were calculated. Mean difference of each treatment were compared by one-way analysis of variance. The signif icant difference within each treatment was compared by DMRT at $5 \%$ signif icance level. Percentage callus induction and percentage somatic embryo induction is non-parametric data so they were first subjected to Arcsine transformation for making the data parametric then analyzed by SPSS. Data of the number of the somatic embryo is also a non-parametric data so they were subjected to log transformation before statistical analysis. After analysis, all the data are retransformed into original data and mentioned in the table. Among the treatments, the average figures followed by a similar letter are not signif icantly different at the $\mathrm{p}<5 \%$ level.

\section{Results and Discussion:}

In the present study, callus induction was demonstrated from leaf explants on MS basal media supplemented with different concentration of Auxin (2,4-D \& NAA) and cytokinin (BAP) alone and in combination. Highest percentage ( $93.33 \%$; Fig.-1) of callus induction was observed on MS basal media supplemented with combination of 0.5 $\mathrm{mg} / \mathrm{L}$ 2,4-D and o.5 mg/L BAP (Plate-1a,b). Many authors reported that individual auxin and cytokinin can induce callus development in different plants (Shahsavari, 2010; Mun \& Mun, 2016). Our finding is in agreement with many authors who worked on different plants to see the effect of different combination of cytokinin and auxin on callusing and different rice cultivar (Ali et al., 2004; Bano et al., 2005; Sahoo et al., 2011; Mohd Din et al., 2016). We also observed that higher concentration of cytokinin and auxin inhibits the callus development in $C$. serratum whereas at lower concentration they promote the callus induction which 


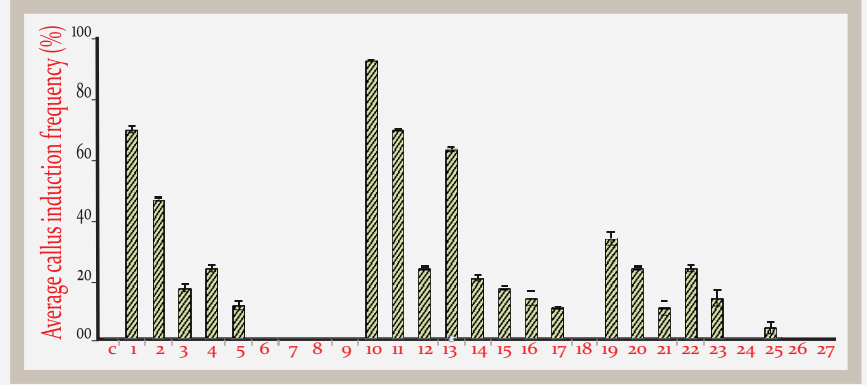

Abbreviations- $\mathrm{C}=$ Control; $1=0.5$ 2,4-D; $2=1.0$ 2,4-D; 3=2.0, 2,4-D; 4=0.5 NAA; $5=1.0$ NAA; $6=2.0 \mathrm{NAA} ; 7=0.5 \mathrm{BAP} ; 8=1.0 \mathrm{BAP} ; 9=2.0 \mathrm{BAP} ; 10=0.5$ 2,4-D+0.5 BAP; $11=0.5$ 2,4-D+1.0 BAP; $12=0.5$ 2,4-D_2.0 BAP; 13=1.0 2,4-D+0.5 BAP; 14=1.0 2,4-D+1.0 BAP; 15=1.0 2,4-D_2.0 BAP; $16=2.0$ 2,4-D+0.5 BAP; $17=2.0$ 2,4-D+1.0 BAP; $18=2.0$ 2,4-D_2.0 BAP; $19=0.5$ 2,4-D+0.5 NAA; $2 \mathrm{O}=0.52,4$-D+1.o NAA; $2 \mathrm{l}=0.5$ 2,4-D+2.0 NAA; $22=1.0$ 2,4-D+0.5 NAA; $23=1.0$ 2,4-D+1.0 NAA; $24=1.0$ 2,4-D+2.0 NAA; $25=2.0$ 2,4-D+0.5 NAA; $26=2.0$ 2,4-D+1.0 NAA; $27=2.0$ 2,4-D+2.0 NAA

Figure-1: Effect of different concentration of auxin and cytokinin on callus induction from leaves of C. serratum L.

resembles many reports conducted on other plants (Aslam et al., 2011; Mujib et al., 2014; Mohd Din et al., 2016, Mun \& Mun, 2016).

For somatic embryogenesis, callus was kept in the MS basal media supplemented with a combination of auxin $(2,4-\mathrm{D} \& \mathrm{NAA})$ and cytokinin (BAP) in different concentrations $(0.25,0.5,1.0,2.0 \mathrm{mg} / \mathrm{L})$. All the cultures were initially kept in the dark for 24 hrs. and then further kept in the $16 / 8$ hrs. LD condition. Induction of somatic embryo and globular stage embryo was observed after 15 days of culture. Results showed that higher frequency of somatic embryos was formed on MS basal media supplemented with a combination of $0.25 \mathrm{mg} / \mathrm{L} 2,4-\mathrm{D}$ and $0.25 \mathrm{mg} / \mathrm{L}$ BAP (Table-1; Plate-1e,f). At higher concentration of growth regulators, somatic embryogenesis was not observed. The formation of somatic embryos was asynchronous, so there were embryos in different stages of development on the same explants. Embryonic structures in the globular and heart-shaped stages were observed in between 15 and 45 days. Development of somatic embryos appeared to progress through globular, heart, and torpedo stages (Plate.-1g,h,i,j, k) of embryo development. In the present study, it was observed that somatic embryos were developed in the combination of 2,4-D and BAP but not alone by 2,4-D and BAP. This suggests that in C. serratum both 2,4-D and BAP (cytokinin) is necessary for somatic embryogenesis. In many plants, it is evident that cytokinins can exert the promotive effect on somatic embryogenesis. Auxins and cytokinin are the main plant growth regulators involved in the regulation of plant cell cycle, division and differentiation and playing key roles in somatic embryogenesis of many species like Brachiaria brizantha (Cabral et al., 2011), Passiflora edulis Sims ( Pinto et al., 2011), Cyclamen persicum (You et al., 2011), Prosopis laevigata (Buendía-González et al., 2012), Rosa hybrida 'Samantha' (Bao et al., 2012), Mango ginger (Raju et al., 2013), Vitis vinifera cv. chardonnay (Dai et al., 2015), Hypoxis hemerocallidea (Kumar et al., 2017), different Chrysanthemum cultivars (May \& Trigiano, 1991; Mandal \&

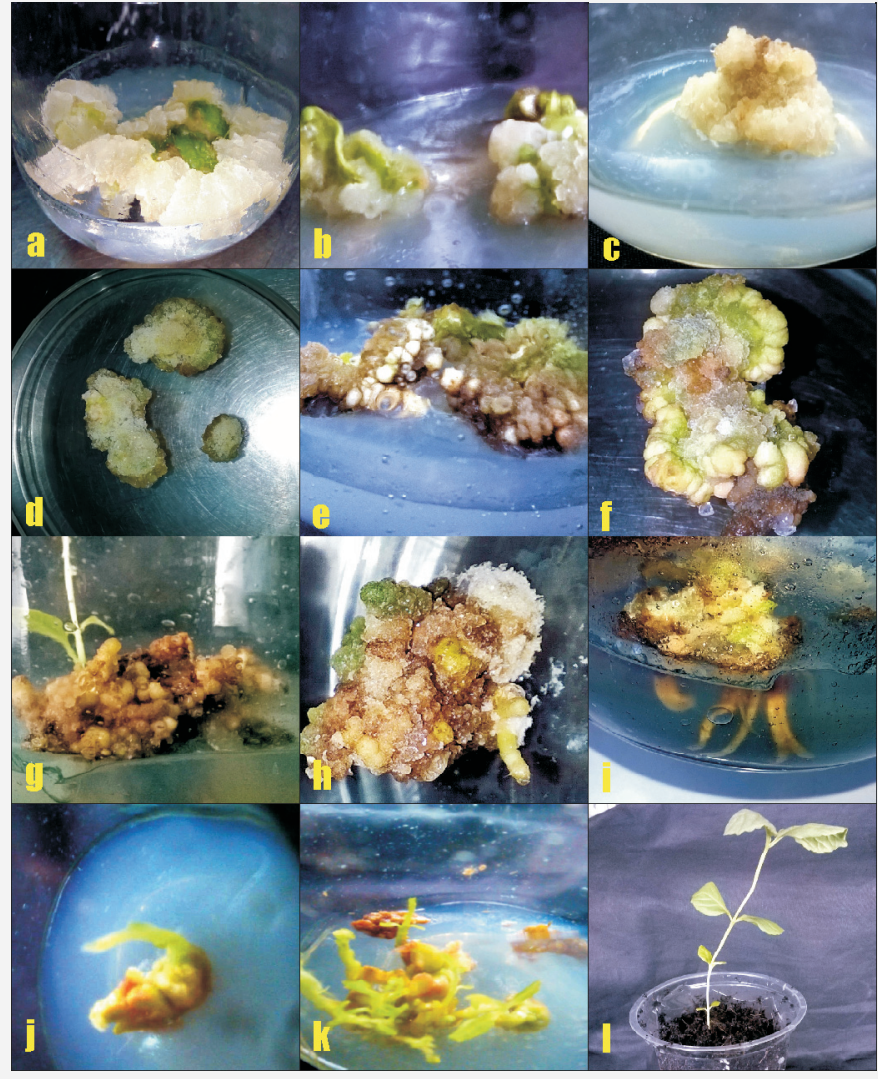

Plate-1: Different developmental stages of indirect somatic embryogenesis and plant regeneration in C. serratum L. (a,b) Callus induction from leaf explants. (c,d) Well developed callus. (e,f) Somatic embryo induction from callus. (g,h,i,j,k) Development of somatic embryo showing different stages i.e. globular, heart shaped, cotyledonary stage and germinating stages (1) Regenerated plantlets

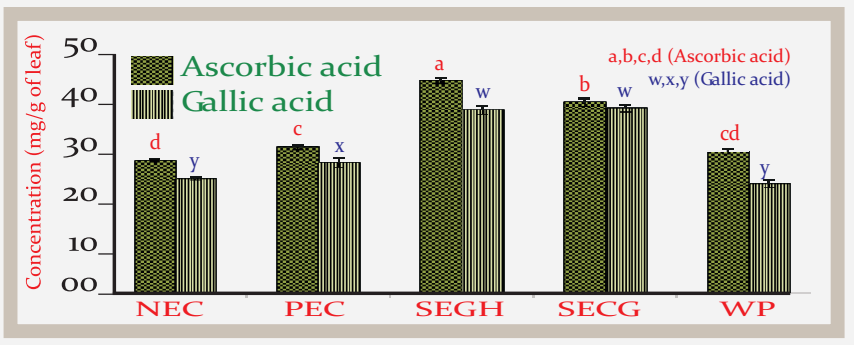

Figure 2: Total Antioxidant activity \& total phenolic content of Methanolic extracts from different growth phase during somatic embryogenesis in $C$. serratum $\mathrm{L}$. Each bar= mean \pm SE $(n=3)$. Same letter are not signif icantly different at $\mathrm{p}<0.05$ according to DMRT.

Datta, 2005; Naing et al., 2013) different Capsicum (Steinitz et al., 2003; López-Puc et al., 2006; Santana-Buzzy et al., 2009). In the present study, asynchronous development of somatic embryos was noticed as reported earlier in Capsicum annuum (Harini and Sita, 1993; Binzel et al., 1996; Steinitz et al., 2003; Kaparakis \&Alderson, 2008) and Capsicum chinense (Solis-Ramos et al., 2010).

A critical step in somatic embryogenesis is the maturation process. The efficient conversion of cotyledonary somatic embryos into plantlets is also an important step for whole plant regeneration and mass proliferation. The globular and heart-shaped stage was seen 
more frequently than torpedo-shaped stages. It was necessary to transfer the somatic embryos to the germination media within 20-30 days, otherwise, dedifferentiation resulting in callus formation. Torpedo stage embryos were separated from explants, subcultured on MS media supplemented with various concentrations of BAP and $\mathrm{Kn}$ for maturation and germination. Subculturing was carried out in every four weeks. Among the different treatments tested, medium supplemented with BAP at 0.5 $\mathrm{mg} / \mathrm{L}$ was found to be most effective for maturation and conversion to whole plantlets (Table-2). Under these conditions, embryos continued germinating, shoots and roots started developing within $17^{-2}-20$ days. The resulat is similar with some other reports on different plant like Anthurium andraeanum (Bhattacharya et al., 2016), Hybanthus enneaspermus (L.) F. Muell (Shekhawat \& Manokari, 2016) and Capsicum baccatum (Venkataiah et al., 2016). Further growth of plantlets was done on the same basal MS medium containing o.5mg/L BAP. Low frequency of cotyledonary stage embryo germination was also observed in growth hormone free basal MS media. Taking these results into consideration, it may be noted that cytokinin has stronger enhancing effects on early and later stage somatic embryonic development in $C$. serratum.

The in vitro grown plantlets were transferred to pots containing autoclaved coco peat and maintained in the controlled environment for 10-15 days for acclimatization (Plate-1l). The regenerated plants showed $72 \%$ survival in the field after transplantation. The regenerated plants did not show any detectable variation in morphology or growth characteristics as compared to the respective donor plants. Natural antioxidants have been extensively studied for their capacity to protect organisms and cells from the damage of oxidative stress associated with aging, degenerative diseases, and cancer (Cozzi et al., 1997). Many studies have shown that phenolic compounds were responsible for antioxidant activity in medicinal plants $(\mathrm{Hu}$ \& Kitts, 2000; Jayasinghe et al., 2003). In the present study, antioxidant activity was determined for NEC, PEC, SEGH, SECG and WP following the method of Prieto et al., (1999). Ascorbic acid was taken as standard and antioxidant activity was determined from linear regression equation of calibration curve $\left[\mathrm{y}=0.004 \mathrm{x}+0.022\left(\mathrm{R}^{2}=0.990\right)\right]$ and expressed as ascorbic acid equivalent in $\mathrm{mg} / \mathrm{g}$ of dry extract. Data revealed that antioxidant activity was maximum in SEGH followed by SECG (Fig.-2). Statistically significant difference in the antioxidant activity of five samples is revealed by ANOVA ( $\mathrm{p}<0.05 ; \mathrm{df}=4,10 ; \mathrm{F}=147.45)$.

The total phenolic contents of five samples were determined from linear regression equation of calibration curve $\left[y=98.71 \mathrm{X}-0.027\left(\mathrm{R}^{2}=0.992\right)\right]$ and expressed as gallic acid equivalent in $\mathrm{mg} / \mathrm{g}$ of dry extract. Among the five samples phenolic content was highest in SEGH and SECG and lowest in NEC and WP (Fig.-2). As per ANOVA result
Table 1: Effect of different concentration of auxin and cytokinin on somatic embryogenesis from callus.

\begin{tabular}{|c|c|c|c|c|}
\hline $\begin{array}{l}\text { Growth } \\
\mathbf{2 , 4 - D}\end{array}$ & $\begin{array}{l}\text { regula } \\
\text { NAA }\end{array}$ & $\begin{array}{l}\text { rs (mg/L) } \\
\text { BAP }\end{array}$ & $\begin{array}{l}\text { \% culture showing } \\
\text { embryogenesis }\end{array}$ & $\begin{array}{l}\text { Mean number of } \\
\text { embryo/explant }\end{array}$ \\
\hline 0.25 & & 0.25 & $83.33 \pm 2.71^{a}$ & $16.67 \pm 0.09^{a}$ \\
\hline 0.25 & & 0.5 & $46.66 \pm 1.92^{c}$ & $7.10 \pm 0.11^{b}$ \\
\hline 0.25 & & 1 & o & o \\
\hline 0.25 & & 2 & o & $\mathrm{O}$ \\
\hline 0.5 & & 0.25 & $60 \pm 3.42^{b}$ & $10.97 \pm 0.12^{b}$ \\
\hline 0.5 & & 0.5 & o & o \\
\hline 0.5 & & 1 & o & $\mathrm{O}$ \\
\hline 0.5 & & 2 & o & o \\
\hline 1 & & 0.25 & o & o \\
\hline 1 & & 0.5 & o & o \\
\hline 1 & & 1 & o & o \\
\hline 1 & & 2 & o & o \\
\hline 2 & & 0.25 & o & o \\
\hline 2 & & 0.5 & o & o \\
\hline 2 & & 1 & o & o \\
\hline 2 & & 2 & $\mathrm{o}$ & o \\
\hline 0.25 & 0.25 & & $53.33 \pm 5.17^{\mathrm{bc}}$ & $9.10 \pm 0.12^{b}$ \\
\hline 0.25 & 0.5 & & $26.67 \pm 6.18^{d}$ & $2.17 \pm 0.08^{c}$ \\
\hline 0.25 & 1 & & $\mathrm{o}$ & o \\
\hline 0.25 & 2 & & o & o \\
\hline 0.5 & 0.25 & & $10 \pm 7.86^{\mathrm{e}}$ & $1.20 \pm 0.06^{\mathrm{c}}$ \\
\hline 0.5 & 0.5 & & o & o \\
\hline 0.5 & 1 & & o & o \\
\hline 0.5 & 2 & & o & o \\
\hline 1 & 0.25 & & o & o \\
\hline 1 & 0.5 & & o & o \\
\hline 1 & 1 & & o & o \\
\hline 1 & 2 & & o & o \\
\hline 2 & 0.25 & & o & o \\
\hline 2 & 0.5 & & o & o \\
\hline 2 & 1 & & o & o \\
\hline 2 & 2 & & o & O \\
\hline Control & & & o & o \\
\hline
\end{tabular}

Each experiment had 10 replications and was repeated thrice. Data are represented by Mean \pm SE within a column followed by the same letters are not signif icantly different at $\mathrm{p}<0.5 \%$ according to DMRT. (Control is hormone free MS medium).

Table 2: Development and germination of somatic embryo from in vitro developed callus of $C$. serratum $\mathrm{L}$. (Mean \pm SE)

\begin{tabular}{lllll}
\hline GR (mg/L) & $\mathrm{a}$ & $\mathrm{b}$ & $\mathrm{c}$ & $\mathrm{d}$ \\
\hline BAP 0.5 & $5.83 \pm 0.72^{\mathrm{a}}$ & $4.07 \pm 0.45^{\mathrm{a}}$ & $3.6 \pm 0.40^{\mathrm{a}}$ & $3.26 \pm 0.37^{\mathrm{a}}$ \\
BAP 1.0 & $2.77 \pm 0.61^{\mathrm{b}}$ & $1.2 \pm 0.29^{\mathrm{b}}$ & $0.93 \pm 0.23^{\mathrm{b}}$ & $0.77 \pm 0.20^{\mathrm{b}}$ \\
BAP 2.0 & $0.43 \pm 0.18^{\mathrm{c}}$ & 0 & 0 & 0 \\
Kn 0.5 & $4.63 \pm 0.84^{\mathrm{a}}$ & $2.03 \pm 0.27^{\mathrm{bc}}$ & $1.86 \pm 0.23^{\mathrm{b}}$ & $1.8 \pm 0.22^{\mathrm{b}}$ \\
Kn 1.0 & $1.00 \pm 0.28^{\mathrm{c}}$ & $0.36 \pm 0.12^{\mathrm{cd}}$ & $0.3 \pm 0.11^{\mathrm{bc}}$ & $0.23 \pm 0.09^{\mathrm{bc}}$ \\
Kn 2.0 & $0.17 \pm 0.08^{\mathrm{c}}$ & 0 & 0 & 0 \\
Control & $2.23 \pm 0.54^{\mathrm{b}}$ & $2.02 \pm 0.35^{\mathrm{bc}}$ & $1.79 \pm 0.29^{\mathrm{b}}$ & $1.7 \pm 0.35^{\mathrm{b}}$ \\
\hline
\end{tabular}

$\mathrm{a}=$ torpedo stage embryo; $\mathrm{b}=$ Embryos converted into cotyledonary stage; $c=$ Embyros germinated; $d=$ Planlets recoverd.

Each experiment had 10 replications and was repeated thrice. Mean \pm SE with same alphabets are not signif icantly different at $\mathrm{p}$ $<0.05$ ( DMRT). 
the phenolic content of five samples is statistically differing $(\mathrm{p}<0.05 ; \mathrm{df}=4,10 ; \mathrm{F}=91.63)$. Result of total phenolic content is also correlated with the result of antioxidant activity which gives strong evidence that phenolics are chiefly responsible for antioxidant activity in C.serratum. Further extraction and purification is needed to know the antioxidant active component from $C$. serratum.

\section{Conclusion:}

This is the first report of in vitro plant regeneration in Clerodendrum serratum L. through somatic embryogenesis. This regeneration protocol can provide large-scale production of C.serratum and can be used for the production of secondary metabolites of pharmacological importance. The present study shows that various factors (Light, temperature, type of growth regulators and their concentration) regulate the production of somatic embryos. From this study, it could be concluded that low hormone concentration is required for somatic embryo induction in C.serratum. Type and concentration of hormone as well developmental stage determine the production of phytochemicals. In the present study, it was reported that antioxidant activity and phenolic content is high in SEGH and SECG as compared to the wild plant. In many reports it has been revealed that in vitro generated plant produces higher amount of secondary metabolites as compared to wild plant (Dakah et al., 2014). It has also been reported in many works that non embryogenic and embryogenic calli can produce a higher concentration of secondary metabolites as compared to wild plants (Kintzios et al., 1999; Mahendran \& Narmatha Bai, 2017). Further research is needed to isolate and identify the most active antioxidant component of C.serratum. It is also needed to see the effect of manipulation in media composition, hormones and environmental condition on the production of important phytochemicals from C.serratum so that the high demand of pharmacologically important metabolites could be accomplished.

\section{Acknowledgements:}

We acknowledge our sincere thanks to BSR UGC scheme (Sanction letter no. L/22/SLS/RSU/2014) for providing fund to carryout research work and Pt. Ravishankar Shukla University, Raipur for providing laboratory facility..

\section{References:}

Ali, S., Qing-zhong, X. \& Xian-yin, Z. (2004): Assessment of various factors involved in the tissue culture system in rice. Rice Sci., 11(5-6):345-349.

Aslam, J., Khan, S.A., Cheruth, A.J., Mujib, A., Sharma, M.P. \& Shrivastava, P.S. (2011): Somatic embryogenesis, scanning electron microscopy, histology and biochemical analysis at different developing stages of embryogenesis in six date palm (Phoenix dactylifera L.) cultivars. Saudi J. Biol. Sci., 18(4):369380.

Bano, S., Jabeen, M., Rahim, F. \& Ilahi, I. (2005): Callus induction and regeneration in seed explants of rice (Oryza sativa vc. Swat II). Pak. J. Bot., 37(3):829-836.
Bao, Y., Liu, G., Shi, X., Xing, W., Ning, G., Liu, J. \& Bao, M. (2012): Primary and repetitive secondary somatic embryogenesis in Rosa hybrida 'Samantha'. Plant Cell Tissue Organ Cult., 109(3):411-418.

Bhattacharya, C., Dam, A., Karmakar, J. \& Bandyopadhyay, T.K. (2016): Erratum to: Direct somatic embryogenesis and genetic homogeneity assessment of regenerated plants of Anthurium andraeanum Linden cv. Fantasia. In Vitro Cell. Develop. Bio., 52(5):512-519.

Bhujbal, S.S., Kewatkar, S., More, L.S. \& Patil, M.J. (2009): Antioxidant Effects of Roots of Clerodendrum serratum Linn. Pharmacog. Res., 1(5):294-298.

Binzel, M.L., Sankhala, N., Joshi, S. \& Sankhla, D. (1996): Induction of direct somatic embryogenesis and plant regeneration in pepper (Capsicum annuum L.). Plant Cell Rep., 15(7):536-540.

Buendía-González, L., Estrada-Zúñiga, M.E., Orozco-Villafuerte, J., Cruz-Sosa, F. \& Vernon- Carter, E.J. (2012): Somatic embryogenesis of the heavy metal accumulator Prosopis laevigata. Plant Cell Tissue Organ Cult., 108(2):287-296.

Cabral, G.B., Carneiro, V.T.C., Lacerda, A.L., do Valle, C.B., Martinelli, A.P. \& Dusi, D.M.A.(2011):Somatic embryogenesis and organogenesis in apomictic and sexual Brachiaria brizantha. Plant Cell Tissue Organ Cult., 107:271-282.

Chopra, R.N., Nayar, S.L., Chopra, I.C., Asolkar, L.V., Kakkar, K.K., Chakre, O.J. \& Varma, B.S. (1956): Glossary of Indian medicinal plants ; [with] Supplement. Pub. by: Council of Scientif ic \& Industrial Research, 1956-92., India.

Cozzi, R., Ricordy, R., Aglitti, T., Gatta, V., Petricone, P. \& De-Salvia, R. (1997): Ascorbic acid and B-carotene as modulators of oxidative damage. Carcinogenesis, 18(1):223-228.

Dai, L., Zhou, Q., Li, R., Du, Y., He, J.,Wang, D., Cheng, S., Zhang, J. \& Wang, Y. (2015): Establishment of a picloram-induced somatic embryogenesis system in Vitis vinifera cv. chardonnay and genetic transformation of a stilbene synthase gene from wild-growing Vitis species. Plant Cell Tissue Organ Cult., 121(2):397-412.

Dakah, A., Zaid, S., Suleiman, M., Abbas, S. \& Wink, M. (2014): In vitro propagation of the medicinal plant Ziziphora tenuior L. and evaluation of its antioxidant activity. Saudi j. Biol. Sci., 21(4):317-323.

Harini, I. \& Sita, G.L. (1993): Direct somatic embryogenesis and plant regeneration from immature embryos of chilli (Capsicum annuum L.). Plant Sci., 89(1):107-112.

Hariprasath, L., Jegadeesh, R., Arjun, P. \& Raaman, N. (2015): In vitro propagation of Senecio candicans DC and comparative antioxidant properties of aqueous extracts of the in vivo plant and in vitro derived callus. S. Afr. J. Bot., 98:134-141.

Hu, C. \& Kitts, D.D. (200o) Studies on the antioxidant activity of Echinacea root extract. JAgric Food Chem., 48(5):1466-1472.

Jayasinghe, C., Gotoh, N., Aoke, T. \& Wada, S. (2003): Phenolics composition and antioxidant activity of Sweet Basil (Ocimum basilicum L.). J. Agric. Food Chem., 51(15):4442-4449.

Jeong, J.H., Jung, S.J., Murthy, H.N., Yu, K.W., Paek, K.Y., Moon, H.K. \& Choi, Y.E. (2005): Production of eleutherosides in in vitro regenerated embryos and plantlets of Eleutherococcus chiisanensis. Biotechnol. Lett., 27(10):701-704.

Kajaria, D.K., Gangwar, M., Sharma, A.K., Nath, G., Tripathi, Y.B., Tripathi, J.S. \& Tiwari, S.K. (2011): Comparative evaluation of phenol and flavonoid content of polyherbal drugs. Pharmacologyonlin. 3:1365-1373.

Kaparakis, G. \& Alderson, P.G. (2008): Role for Cytokinins in 
Somatic Embryogenesis of Pepper (Capsicum annuum L.)? J. Plant Growth Reg., 27(2):110-114.

Keshava Murthy, K.R. (1994): Medicinal Plants of Karnataka. Pub. by: Karnataka Forest Dept., Bangalore, India. 399p.

Kintzios, S., Nikolaou, A. \& Skoula, M. (1999): Somatic embryogenesis and in vitro rosmarinic acid accumulation in Salvia officinalis and $S$. fruticosa leaf callus cultures. Plant Cell Rep., 18(6):462-466.

Kumar, V. \& Chandra, S. (2014): High frequency somatic embryogenesis and synthetic seed production of the endangered species Swertia chirayita. Biologia,69(2):186-192.

Kumar, V., Moyo, M. \& Staden, J.V. (2017): Somatic embryogenesis in Hypoxis hemerocallidea?: An important African medicinal plant. S. Afr. J. Bot., 108:331-336.

López-Puc, G., Canto-Flick, A., Barredo-Pool, F., Zapata-Castillo, P., Montalvo-Peniche, M., Barahona-Pérez, F. \& SantanaBuzzy, N. (2006): Direct somatic embryogenesis: A highly efficient protocol for in vitro regeneration of Habanero pepper (Capsicum chinense Jacq.). Hort Science., 41(6):1-7.

Mahendran, G. \& Narmatha Bai, V. (2017): Plant regeneration through direct somatic embryogenesis, antioxidant properties, and metabolite profiles of Swertia corymbosa (Griseb.) Wight ex C.B. Clarke. Plant Biosys., 151(1):39-49.

Mandal, A.K.A. \& Datta, S.K. (2005): Direct somatic embryogenesis and plant regeneration from ray florets of Chrysanthemum. Biol. Plantarum, 49(1):29-33.

Manjkhola, S., Dhar, U. \& Joshi, M. (2005): Organogenesis, embryogenesis, and synthetic seed production in Arnebia euchroma- A critically endangered medicinal plant of the Himalaya. In Vitro Cell. Dev. Biol., 41(3):244-248.

Martin, K.P. (2004): Plant regeneration through somatic embryogenesis in medicinally important Centella asiatica L. In Vitro Cell Dev. Biol., 40(6):586-591.

May, R.A. \& Trigiano, R.N. (1991): Somatic embryogenesis and plant regeneration from leaves of Dendranthema grandiflora. L. Am. Soc. Hortic. Sci., 116(2):366-371.

Ming-Hua, Y. \& Sen-Rong, H. (2010): A simple cryopreservation protocol of Dioscorea bulbifera L. embryogenic calli by encapsulation-vitrification. Plant Cell Tiss. Organ Cult., 101(3):349-358.

Mohd Din, A.R.J., Ahmad, F.I., Rahman, A., Wagiran, A., Samad, A.A., Rahmat, Z. \& Sarmidi, M.R. (2016): Improvement of efficient in vitro regeneration potential of mature callus induced from Malaysian upland rice seed (Oryza sativa cv . Panderas ). SaudiJBiolSci., 23(1):S69-S77.

Mujib, A., Ali, M., Isah, T. \& Dipti, (2014): Somatic embryo mediated mass production of Catharanthus roseus in culture vessel (bioreactor) - A comparative study. Saudi j. Biol. Sci. 21(5):442-449.

Mun, S.C. \& Mun, G.S. (2016): Development of an eff icient callus proliferation system for Rheum coreanum Nakai, a rare medicinal plant growing in Democratic People's Republic of Korea. Saudij. Biol.Sci., 23(4):488-494.

Naing, A.H., Kim, C.K., Yun, B.J., Jin, J.Y. \& Lim, K.B., (2013): Primary and secondary somatic embryogenesis in Chrysanthemum cv. Euro. Plant Cell Tiss. Organ Cult., 112(3): 361-368.

Pinto, D.L.P., Almeida de, A.M.R., Rego, M.M., Silva da, M.L., Oliveira de, E.L. \& Otoni, W.C. (2011): Somatic embryogenesis from mature zygotic embryos of commercial passionfruit (Passiflora edulis Sims) genotypes. Plant Cell
Tiss. Organ Cult., 107(3):521-530.

Prieto, P., Pineda, M. \& Aguilar, M. (1999): Spectrophotometric quantitation of antioxidant capacity through the formation of a phosphomolybdenum complex: specific application to the determination of vitamin E. Anal. Biochem., 269(2):337341.

Raju, C.S., Kathiravan, K., Aslam, A. \& Shajahan, A. (2013): An efficient regeneration system via somatic embryogenesis in mango ginger (Curcuma amada Roxb.). Plant Cell Tiss. Organ Cult., 112(3):387-393.

Reinert, J. (1958): Morphogenese und ihre Kontrolle an Gewebekulturen aus Carotten. Naturwissenschaften. 45(14):344-345.

Sahoo, K.K., Tripathi, A.K., Pareek, A., Sopory, S.K. \& SinglaPareek, S.L. (2011): An improved protocol for efficient transformation and regeneration of diverse indica rice cultivars. Plant Methods, 7(1):49-59.

Santana-Buzzy, N., Lopez-Puc, G., Canto-Flick, A., Barredo-Pool, F., Balam-Uc, E., Aviles-Vinas, S., Solis-Marroquin, D., Lecona-Guzman, C., Bello-Bello, J.J., Gomez-Uc, E. \& Mijangos-Cortes, J.O. (2009): Ontogenesis of the somatic embryogenesis of Habanero pepper (Capsicum chinense Jacq.). Hort Sci., 44(1):113-118.

Shahsavari, E. (2010): Evaluation and optimizations of media on the tissue culture system of upland rice. Int. J. Agri. Biol., 12(4):537-540.

Shekhawat, M.S. \& Manokari, M. (2016): Somatic embryogenesis and in vitro flowering in Hybanthus enneaspermus (L.) F. Muell. - A rare multipotent herb. Asian Pac. J. Repro., 5(3):256-262.

Slinkard, K. \& Singleton, V.L. (1977): Total Phenolic analysis: automation and comparison with manual methods. Am. J. Enol. Viticul., 28(1):49-55.

Solis-Ramos, L., Nahuath-Dzib, S., Andrade-Torres, A., BarredoPool, F., Gonzalez-Estrada, T. \& Serna, E. (2010): Indirect somatic embryogenesis and morphohistological analysis in Capsicum chinense. Biologia, 65(3):504-511.

Steane, D.A., Scotland, R.W., Mabberley, D.J., Wagstaff, S.J., Reeves, P.A. \& Olmstead, R.G. (1997): Phylogenetic Relationships of Clerodendrum s . 1 . ( Lamiaceae ) Inferred from Chloroplast DNA. Systamatic. Bot., 22(2):229-243.

Steinitz, B., Kusek, M., Tabib, Y., Paran, I. \& Zelcer, A. (2003): Pepper (Capsicum annuum L.) regenerants obtained by direct somatic embryogenesis fail to develop a shoot. In Vitro Cell. Dev. Biol., 39(3):296-303.

Steward, F., Mapes, M. \& Mears, K. (1958): Growth and organized development of cultured cells. II. Organization in cultures grown from freely suspended cells. Am. J. Bot., 45(10):705708.

Venkataiah, P., Bhanuprakash, P., Kalyan, S.S. \& Subhash, K. (2016): Somatic embryogenesis and plant regeneration of Capsicum baccatum L. J. Gen. Eng. Biotechnol., 14(1):55-6o.

Verma, S.K., Das, A.K., Cingoz, G.S., Ulsu, E. \& Gurel, E. (2016): Influence of nutrient media on callus induction, somatic embryogenesis and plant regeneration in selected Turkish crocus species. Biotechnol. Rep., 10: 66-74.

You, C.R., Fan, T.J., Gong, X.Q., Bian, F.H., Liang, L.K. \& Qu, F.N. (2011): A high frequency cyclic secondary somatic embryogenesis system for Cyclamen persicum Mill. Plant Cell Tissue Organ Cult., 107(2):233-242. 